\title{
As Marchas Prosaicas de um Grupo Guarani-Mbyá
}

Sílvia Guimarães Na contemporaneidade, a vida social guarani-mbyá é marcada por uma territorialidade IPHAN transitória, como já foi amplamente discutido em muitos trabalhos sobre essa etnia². Ladeira (1992), em seus estudos precursores a respeito dos guarani-mbyás, discutiu o fato de essa etnia expandir o seu espaço até atingir o mar, limite, à primeira vista, intransponível, mas possível de ser superado quando os humanos se tornam imortais e o ultrapassam, alcançando a terra sem mal. Em suas migrações, os guarani-mbyás realizam duas formas de deslocamento: uma ritual, que acontece quando buscam a morada dos seres imortais, e outra prosaica, que ocorre quando caminham pelas diversas aldeias mbyás, tecendo uma rede de reciprocidade. Esse último modo de deslocamento será tema deste artigo a partir da análise do caso dos guarani-mbyás localizados no estado do Espírito Santo, na aldeia Tecoa Porã, Boa Esperança.

Esse grupo realizou uma marcha cerimonial em busca da terra sem mal, guiado por uma líder política e religiosa, que durou aproximadamente trinta anos (Ciccarone 1996 e 2001; Guimarães 2001 e 2004). Em meio a essa marcha extraordinária, os mbyás de Tecoa Porã, constantemente, deslocavam-se por motivos prosaicos. Essas duas formas de peregrinação se complementavam, ambas desencadeavam uma singular ocupação espacial. Nas marchas prosaicas, os mbyás atualizavam ou vivificavam o seu território, enquanto nas marchas cerimoniais, eles o expandiam. Nesse sentido, os dois tipos de deslocamento estavam inter-relacionados e determinavam a ocupação espacial do grupo. Em outro trabalho, tratei do significado da marcha ritual em busca da terra sem mal (Guimarães 2004). A seguir, procuro compreender o significado das rotas ordinárias sobre determinado território.

A profetisa, líder do grupo de Tecoa Porã, dava a forma e a direção tanto de uma rota extraordinária quanto de uma ordinária. Portanto, na discussão que segue observo o papel da liderança na conformação dessas trilhas. Porém, antes de entrar no caso específico de Tecoa Porã, faço alguns comentários sobre a maneira como os guaranis, no século XVI, ocuparam e dinamizaram espaços sociais, o que irá problematizar o caso em questão. 
Segundo Melià (1990:30) e Bartolomé (1989:407), na era da colonização, os guaranis ${ }^{3}$ construíam "aldeias agrícolas" e eram vistos pelos cronistas como "gente lavradora". As aldeias, onde se misturavam espaço místico, físico, econômico e político, tinham um ritmo de vida mais sedentário, ou melhor, essas unidades sociais não acompanhavam o ritmo "migratório" de vida dos profetas. Talvez, a predominância da guerra e a formação de uma socialidade marcadamente guerreira tivessem também contribuído para esse tipo de dinâmica social. A figura do xamã-profeta, no século XVI, estava relacionada com um tipo de ocupação espacial um pouco distinta da realizada pelo guerreiro, ou seja, ele tinha uma "liberdade" na conquista de espaços, alcançava regiões interditadas a um guerreiro, as aldeias inimigas. Além disso, a preocupação fundamental desse xamã era com o espaço celeste, a terra sem mal, enquanto a preocupação do guerreiro era com o tempo futuro ${ }^{4}$. Nessa época, as atividades bélicas orientavam as ações e movimento dos guaranis, o que, conseqüentemente, produzia uma singular ocupação espacial.

$\mathrm{Na}$ literatura seiscentista, Soares encontrou a disposição e a organização do espaço social guarani no vocabulário desse povo:

“No primeiro nível, está a família extensa, ou teýy, em segundo lugar, o conjunto de casas que abrigam estas famílias extensas, a aldeia ou amundá; em terceiro, o conjunto de aldeias que estão inseridas em um território, ou teko'á; em quarto e último, o conjunto de teko'ás que forma uma "região" ou “província" ou guará" (1997:122).

As chefias nessas instâncias eram exercidas conforme a unidade organizacional tratada. Desse modo, desde a família extensa (teýy) até a província (guará), existiam lideranças específicas para cada unidade. Poderosos guerreiros fundavam e determinavam a constituição e a coesão de uma unidade social e as regras de residência de seus membros. Alguns líderes eram tão prestigiados que eles tinham a capacidade de reunir centenas de guerreiros e de canalizar as atividades bélicas em situações de conflito extremo (Soares 1997:117). Produziam níveis de unidades sociais diferenciados, isto é, desde aldeias até províncias, que apresentavam diversos níveis de interação umas com as outras. De acordo com Soares (1997:134), o "guerreiro mais antigo", fundador de uma aldeia (amundá), era relembrado nos discursos dos líderes subseqüentes como aquele que viveu plenamente as tradições e como o exemplo que deveria ser seguido. Esporadicamente, algum xamã poderia dar forma a uma unidade social (teýy ou amundá), principalmente quando eram desencadeadas as marchas cerimoniais ${ }^{5}$.

No início da colonização, a família extensa foi interpretada por Soares (op. cit.) como o núcleo básico, pois nela um líder-guerreiro iniciava a construção de seu prestígio. Por sua vez, as regióes (guará) guaranis surgiam através de uma rede de interação que unia diversas localidades (teko'á $)$. Nesta teia social, um líder, em especial, mobilizava outros chefes em um mesmo projeto. Um grande chefe, reconhecido numa dada província, consolidava seu prestígio através de contínuas trocas que estabelecia com os líderes de diversas aldeias (amundá). Isto garantia certa mobilidade de homens e mulheres dentro de uma região, dava a forma da ocupação espacial dos guaranis e gerava uma rede de reciprocidade. Tal rede estava, no século $\mathrm{XVI}$, intrinsecamente relacionada com as guerras e acontecia quando havia festividades, repastos canibais e intercâmbio de cônjuges. Todas estas atividades 
promoviam, mais que limites físicos, um sentimento de identidade por reforçarem a solidariedade e a dádiva no interior da região. A recusa de um convite significava uma futura retaliação.

Os pontos apresentados acima, baseados nos relatos dos cronistas acerca dos guaranis do século XVI e encontrados nos trabalhos de Melià (1990), Soares (1997) e Bartolomé (1989), apresentam temas centrais que pretendo abordar a seguir, em um caso recente vivido por um grupo mbyá. Tais temas são a ocupação espacial e o papel do xamã no desenho desse território.

Os guarani-mbyás de Tecoa Porã, obviamente, apresentaram novidades em relação aos tupinambás e aos guaranis do século XVI. Essas diferenças são interessantes pois, no caso de Tecoa Porã, não era a figura do guerreiro que persistia como ocorria entre os tupinambás e guaranis do século XVI. Mas havia sim a presença marcante do xamã ${ }^{7}$, semelhante ao carai (xamã-profeta) do século XVI, aquele que caminhava permanentemente ao mesmo tempo em que profetizava entre as diversas comunidades. Personagem central da vida social em Tecoa Porã, o xamã tinha um espantoso poder de persuasão, uma habilidade discursiva, uma grande eloqüência. Os mbyás, no caso em questão, baseavam-se nesse tipo de xamã para realizar ritos e vivenciar outras práticas, todas voltadas para a elaboração da pessoa mbyá (Guimarães 2001). Além disso, esse profeta, temido e respeitado, era o referencial na organização social, como veremos a seguir. Outro elemento marcante em Tecoa Porã estava nos tipos de práticas sociais realizadas que garantiam a imortalidade, pois não eram as façanhas bélicas as privilegiadas, mas sim as ações relacionadas com o xamanismo, i.e., caminhar, jejuar, dançar e cantar incessantemente (Guimarães 2004).

\section{UM GRUPO MBYÁ DA CONTEMPORANEIDADE VISTO SOB SUAS ROTAS ORDINÁRIAS}

Em Tecoa Porã, uma mulher foi a protagonista na cena da vida social. Era a cunhã carai (xamã-profetisa) que fundou e orientou o grupo de Tecoa Porã na busca pela morada dos imortais. Essa unidade social foi formada ao redor dela, que conseguiu agregar mais e mais pessoas e mantê-la coesa até mesmo depois de sua morte, em 1994. A lembrança da gravidade dos gestos e das palavras desta mulher, ainda, faz permanecer Tecoa Porã. Nessa perspectiva, pode-se dizer que esse grupo mbyá atualiza uma socialidade xamânica, na qual o xamã-profeta promove as condições das trocas generalizadas de bens, pessoas e informações, organiza também o social e orienta sobre as formas do agir. No grupo da profetisa, era ela que intervinha no ingresso de estranhos na aldeia e na saída de seus membros para outras localidades.

A ocupação espacial dos guarani-mbyás de Tecoa Porã nunca esteve reduzida à construção de uma aldeia (tecoa, teco = modo de ser; $a$ = local), pois a sua territorialidade era transitória e dependia de uma expansão continuada. Vivia-se em uma aldeia até se desfazer a ambiência que garantia o acesso à terra sem mal. O movimento que orientava a conquista de novas áreas era impulsionado pelo desgaste tanto dos modos de produção quanto da ambiência religiosa da aldeia, esta última percebida como força dinâmica e elemento constitutivo do ethos mbyá. Assim, novos espaços deveriam ser conquistados, isto é, novas aldeias deveriam ser construídas, sem perder 
de vista os locais por onde eles estiveram anteriormente. Isto provocava a expansão do território. As marchas cerimoniais davam a feição dessa dilatação, uma vez que o caminhar sacro forçava a conquista e a ocupação plena de novos horizontes. $\mathrm{O}$ trajeto que levava à morada celeste era indicado pelo demiurgo Nhãde $R u$ à profetisa e, a partir dessa trilha, novas áreas eram conquistadas. Ela não conhecia a localização geográfica da terra sem mal, mas dominava as regras éticas que propiciavam seu acesso. Provavelmente as novas localidades, que podiam se tornar aldeias, ficavam na direção do nascente, à beira do litoral atlântico, em montes com cobertura florestal, pois em locais com estas características estavam as "casas de pedra" (tava) onde viveram os mbyás imortalizados da terra original. Ladeira (1992) explorou e revelou a importância dessa idéia no complexo formado pela mata atlântica e litoral na sócio-cosmologia mbyá.

Concomitantemente a essa marcha cerimonial, em Tecoa Porá, aconteciam deslocamentos desencadeados por motivos prosaicos. Era possível perceber que a permanência continuada na aldeia angustiava, especialmente, os homens. Essa sensação se manifestava em situações cotidianas, por exemplo, na insistência de um homem adulto em pedir passagens de ônibus a um funcionário do governo para visitar os parentes de sua esposa em uma aldeia de São Paulo, ou na vontade de outros de trabalhar fora da aldeia com o intuito de sair momentaneamente da vida cotidiana ${ }^{8}$. As viagens constantes que os homens da aldeia realizavam, o fato de seis dos quartoze homens da aldeia estarem em viagem quando estive lá, confirmavam que ficar por muito tempo na aldeia não era o ideal para eles. Por sua vez, em sua grande maioria, as mulheres deveriam permanecer por mais tempo na comunidade. A continuidade e a sobrevivência de Tecoa Porã dependiam muito das mulheres, principalmente por elas dominarem a atual fonte de subsistência, o turismo, mesmo falando pouco da língua portuguesa. Essas mulheres vendiam o artesanato com o auxílio daquelas que dominavam um pouco mais o português. Não havia a necessidade de explanar acerca do que se estava vendendo; o artesanato ficava em exposição, o valor era dito e a compra e venda eram realizadas. $O$ grupo se fazia, nitidamente, com a presença fixa de mulheres (casadas ou casáveis) e crianças e com a presença em movimento dos homens. Havia dezessete mulheres, quarenta e uma crianças e quatorze homens nesta comunidade em 1997. No período em que estive lá, seis desses homens estavam constantemente em viagem, enquanto somente uma mulher havia se ausentado com o seu cônjuge para trazer sua mãe e irmãos, os quais iriam morar com o grupo. Homens e mulheres coexistiam; elas, por sua vez, eram o substrato espacialmente estável da ação masculina. A aparente necessidade dos homens de estar em movimento e das mulheres de permanecer na aldeia tinha como uma possível explicação a procedência das almas ou porções imortais que haviam encarnado nas pessoas no momento do nascimento e que são reveladas nos nomes ${ }^{9}$. Assim, os nomes, que indicavam determinada conduta, revelavam que algumas pessoas deveriam se ausentar da aldeia, enquanto outras deveriam permanecer.

De acordo com Kramer (1988:181), pode-se dizer que existiam etapas na marcha masculina guarani ${ }^{10}$ que se aplicavam ao caso de Tecoa Porã. Alguns homens permaneciam na sua aldeia de origem até a idade aproximada de 16 ou 17 anos, quando estavam prontos para se casarem. A partir daí, eles começavam a percorrer, por tempos variáveis, diversas localidades, onde o líder de sua aldeia de origem tinha alianças. Em alguma dessas localidades, 
o jovem poderia se casar e manter residência até o nascimento do primeiro filho. Depois disso, o jovem com sua família seria atraído e manteria uma residência na aldeia que tivesse um chefe com grande prestígio e poder de influência sobre ele e sua mulher. Após realizar tal percurso, ao longo de sua juventude, o homem teria vivificado uma rede de trocas econômicas, políticas, espirituais, que seria acionada, constantemente, durante o resto de sua vida. Segundo Kramer (1988:88), duas características marcavam a dinâmica organizativa de uma sociedade guarani: a fragmentação periódica dos grupos residenciais e o relativo antagonismo entre as chefias.

A cisão da aldeia e as partidas e entradas de pessoas davam a feição elástica da demografia de Tecoa Porã. Com a morte da profetisa, o número de habitantes diminuíra drasticamente e acontecera uma cisão no interior do grupo. Algumas pessoas fundaram outra aldeia nas proximidades da original. A contigüidade dessa outra parcialidade acentuava o trânsito de pessoas, o qual ampliava e reduzia o tamanho de um dos grupos em momentos de crise.

Nas marchas prosaicas desse grupo mbyá, as pessoas dinamizavam níveis de organização social relativos aos espaços. Em Tecoa Porã, os mbyás pareciam dinamizar as categorias de teýy, teko'á e guará tratadas por Soares (1997) no caso dos guarani do século XVI, obviamente com especificidades e significados distintos. Eles imaginavam a teko'á (op. cit) como englobando a família extensa originária, isto é, a da profetisa, e os mbyás de outras localidades que foram incorporados ao grupo. Tratava-se, portanto, do espaço onde as pessoas estavam vinculadas à figura da poderosa líder espiritual. Mesmo após a sua morte, as pessoas desse grupo ainda viviam da memória dessa mulher, como uma força que dava sentido à unidade social. Talvez, quando tal lembrança se esvaísse, o grupo seria desfeito e outro surgiria em seu lugar. Havia no grupo de Tecoa Porã a idéia de uma ocupação social e organização social semelhante a uma região que englobava várias tecoa. Os mbyás de Tecoa Porã se viam como membros de uma parcialidade/tecoa, situada em uma rede de intercâmbio social e econômico. Eles exemplificavam um grupo que continuava apresentando uma região altamente interativa. Segundo Melià (1990:45), os guaranis viviam em uma "economia da reciprocidade", que acontecia por meio de convites para cerimônias, alianças matrimoniais etc. Em Tecoa Porã, essas ações recíprocas ocorriam tanto no interior da aldeia quanto da região da qual o grupo fazia parte.

O território ou a região dos mbyás de Tecoa Porã era composto de aldeias com as quais eles mantinham alguma interação, de acampamentos por onde passaram, de rotas que ligavam as aldeias e os acampamentos e, também, de caminhos "secretos" que levavam à terra sem mal e que só os profetas conheciam depois de serem revelados por Nhãde Ru. Os deslocamentos prosaicos dinamizavam e mantinham a coesão deste território. Poderia ser dito que, até o momento, a ocupação espacial do grupo de Tecoa Porã compreendia parte do Paraguai e dos estados brasileiros do Rio Grande do Sul, Paraná, Santa Catarina, São Paulo, Rio de Janeiro e Espírito Santo. Por esses lugares, os mbyás mantinham algum tipo de interação. A meu ver, este grupo parecia ter construído uma região que era sua área de atuação. Nesse sentido, o território de um grupo estava sobreposto aos territórios de outros grupos. Era possível imaginar a área de atuação da aldeia de Tecoa Porã como uma dimensão que acontecia ao mesmo tempo e no mesmo espaço da região de atuação de outro grupo. Vários territórios eram realizados 
simultaneamente e um não danificava o outro porque o espaço ou o território era um valor menor diante do movimento realizado sobre ele.

Em Tecoa Porã, as pessoas imaginavam uma região de atuação como englobando as aldeias com as quais a profetisa havia estabelecido alianças. Nessa dimensão espacial, os mbyás conviviam, constantemente, com pessoas de diversas localidades. A profetisa era reconhecida e é lembrada ainda hoje como uma poderosa e influente xamã na vasta área de interação de sua aldeia. Alguns trabalhos sobre os guarani-mbyás de aldeias localizadas em Santa Catarina, Rio de Janeiro e São Paulo revelam que os moradores desses grupos temiam, veneravam e respeitavam a profetisa de Tecoa Porã (Litaiff 1999; Ladeira 1992). Seu renome estendia-se por um vasto território. Ela conseguia atrair muitos para a unidade social onde vivia e determinar a residência ${ }^{11}$ de seus descendentes tanto masculinos quanto femininos. Em tais casos, foi possível ver grupos de agnatos dando proteção ou atraindo para a aldeia onde viviam seus parentes afins e consangüíneos em momentos de crise. Eles aumentavam, com essa atitude, 0 prestígio da profetisa. Numa dada região, grupos de agnatos configuravam uma rede de moradia temporária ou permanente. Contudo, essa atração dos agnatos dependia da liderança sob a qual viviam. Os guaranis abandonavam e receavam as aldeias fundadas por xamãs ameaçadores ou as que não tinham xamãs.

O trânsito de informações era um momento importante na província mbyá. Também os ameríndios do século XVI, de acordo com Soares (1997:147), no seu vasto território, comunicavam-se, espalhavam as novidades e mantinham-se informados sobre os acontecimentos. A visita de parentes ou de mensageiros (pareha ${ }^{12}$ ) era responsável pela abertura dessas rotas de informações. Tais mensageiros tinham um papel importante, pois anunciavam a visita de alguma liderança ou convites para festas, rituais e guerras (op. cit.:149). As pessoas seguiam os caminhos ou as trilhas no interior das matas que ligavam as aldeias de uma região ou de várias regiões. Em Tecoa Porã, essas rotas de informações aconteciam por meio da visita de parentes que compartilhavam as novidades e faziam convites para festas e rituais. Receber visitas revela o prestígio de uma aldeia, do líder e, também, do anfitrião. Convidar e ser convidado eram momentos fundamentais da economia de reciprocidade mbyá. Talvez a angústia de um homem por não sair de sua aldeia mostrava a sua falta de prestígio e, além disso, a necessidade de transitar por essas rotas de informações, por onde fluía a fala. Caminhar por essas trilhas também significava seguir os passos dos profetas, exercitar os corpos e completar uma etapa do processo de transcendência da condição humana.

Os mbyás circulavam, faziam ações conjuntas e re-atualizavam os vínculos com os membros de outras localidades, ou seja, eles permaneciam em movimento, exercitando uma rede de intercâmbio numa dada região. Atualmente, o trânsito de pessoas por rotas ordinárias acontecia, por exemplo, para que elas se reunissem em uma aldeia, realizassem assembléias e se organizassem em busca de reivindicações frente ao Estado. As pessoas transitavam também para sanar os conflitos agravados na localidade de origem; para encontrar um cônjuge; para participar de um ritual de nominação; para passar informações; em busca de melhores condições de vida, isto é, de condições "espirituais", em aldeias onde moravam xamãs. As pessoas de Tecoa Porã desenvolviam essas caminhadas individualmente ou com a companhia do cônjuge ou, ainda, com esse e os filhos. Tais migrações 
prosaicas eram sempre uma alternância entre a carência e a plenitude de condições que garantiam o bom viver na aldeia. Pretendia-se ter na tecoa a harmonia que permitiria o acesso ao paraíso celeste. Entretanto, a instabilidade e a fragilidade, muitas vezes, marcavam o grupo. Uma das preocupações do líder, fundador de uma unidade social, era manter o bom modo de viver, pois os grupos não eram homogêneos e indivisos, e a harmonia era resultado de um intenso trabalho político. No interior de Tecoa Porã havia conflitos, rivalidades, desentendimentos, os quais requeriam da profetisa habilidade para refazer, todos os dias, as alianças e o estado de harmonia. Por outro lado, nas relações com o exterior, dentro de uma região, ela se preocupava em criar ações recíprocas com as lideranças de outras aldeias. As pessoas, os bens e as festividades que ela tinha à sua disposição eram usados nessas ações para incrementar o seu prestígio e permitir a reprodução social do grupo.

Era possível ver a grande região dos mbyás de Tecoa Porã a partir do fluxo constante das pessoas entre diversas aldeias. Ao representar mais que limites físicos, a região expunha um valor de pertencimento, o qual era reforçado e estabelecido por condutas solidárias. Significava, portanto, uma reunião de unidades sociais mbyás, ligadas por laços sociais, de reciprocidade, de aliança e de identidade grupal, sendo, ao mesmo tempo, espaço físico, social e político. A região se referia, também, ao fluxo da língua, isto é, a uma rede de comunicação e circulação de informações. A fala surgia abrindo os caminhos que ligavam as aldeias distribuídas por um vasto território. A região assemelhava-se a uma teia, na qual os pontos nodais eram as aldeias (tecoa) e as linhas que ligavam tais pontos eram os caminhos abertos pela fala, onde os mbyás praticavam sua economia da reciprocidade e a experiência fundamental do caminhar.

\section{DESCARTANDO O ESTÁTICO E CAPTANDO MOVIMENTOS}

Como vimos anteriormente, na cena da vida social de Tecoa Porã, a mobilidade provocava uma superposição de territórios de diversos grupos sem provocar conflitos. As lembranças constantes e intensas da profetisa e de suas orientações na marcha cerimonial e no fluxo de pessoas pelas rotas ordinárias promoviam a necessidade de transitar, construir uma região de atuação e, principalmente, transcender a condição humana e alcançar a terra sem mal como imortais. Por conviverem com essa possibilidade de poder desencadear um movimento a qualquer instante, as pessoas dessa localidade pareciam ter criado um modo de interação com o branco que evitava confrontos desgastantes, como veremos a seguir.

O grupo de Tecoa Porã dividia uma mesma terra indígena com a etnia tupiniquim. Esses últimos pretendiam, com a ajuda de uma instituição religiosa, o Conselho Indigenista Missionário - CIMI, ampliar sua terra, ao englobar plantações de eucalipto da empresa Aracruz Celulose ${ }^{13}$. Para discutir o problema da ampliação, essa instituição religiosa e os tupiniquins realizavam freqüentemente reuniões nas aldeias dos tupiniquins. Em tais reuniões, eles exigiam sempre a presença do cacique mbyá. Contudo, esse cacique estava preocupado em viver sua existência no movimento que sua alma-nome, provinda da região do ser sobrenatural Tupã, exigia. Geralmente, viajava 
nos dias em que aconteciam os encontros. Outros homens, que estavam disponíveis, substituíam-no. Contudo, a instituição religiosa e as lideranças tupiniquins não aprovavam essa atitude do cacique e exigiam a presença dele nas reuniões, nas quais, segundo eles, decisões importantes deveriam ser tomadas pelos líderes. Havia um desencontro semântico sobre a idéia de liderança entre membros da nossa sociedade, da tupiniquim e da mbyá. $O$ cacique era uma liderança imaginada e concebida pelo branco para lidar com o mesmo. Os mbyás não reconheciam o cacique como um líder prestigioso, semelhante à profetisa; conseqüentemente, ele nunca poderia guiar ou orientar o grupo de Tecoa Porã em qualquer empreendimento. Por isso, qualquer homem adulto da aldeia se tornava um representante legítimo nas reuniões com os brancos. Além dessa divergência sobre a idéia de liderança, existia, também, um desacordo semântico sobre o problema da terra indígena.

Em certa ocasião, uma anciã mbyá me esclareceu sobre essa atitude do cacique, que era seu filho, com relação às reuniões que tinham como fim discutir o problema da ampliação e da inclusão de plantios de eucalipto na terra onde moravam. Ela me alertou para o fato de que eles, os mbyá, não queriam essa terra fraca e doente, recoberta com plantações de eucalipto. Eles não se interessavam por essa plantação nociva, feita pelo branco, mas por áreas onde havia a mata original. Por sua vez, os tupiniquins acreditavam que poderiam fazer um bom uso da madeira do eucalipto e poderiam reflorestar a área. Os mbyás desencadeavam uma discussão e faziam suas reivindicações frente à sociedade nacional quando o assunto dizia respeito ao bom modo de viver guaranimbyá e o que esse modo de viver implicava. Os mbyás fizeram isso quando necessário, enfrentaram abertamente a empresa florestal quando ela queria ocupar o local sagrado onde eles deveriam construir o tecoa e onde os tupiniquins viviam. Ao longo desse processo, o silêncio e o movimento conformavam maneiras de escapar da densa e difícil presença dos brancos.

Os mbyás de Tecoa Porã tinham um cuidado constante em lidar com os brancos, que era visível na forma como eles evitavam a presença de algumas pessoas e agiam com turistas e funcionários do governo. Lembravam com orgulho do dia em que a profetisa retirara da aldeia um casal inconveniente de uma instituição religiosa que questionara sua autoridade e pretendera estabelecer outra liderança na aldeia. A profetisa sabia quando e como reagir aos males que afetavam este mundo. Quando os mbyás lembravam dela e de suas atitudes, eles enfatizavam a leveza, a elegância e a delicadeza de seus atos e gestos. Acredito que nessa forma de discursar e agir estava todo o poder de persuasão e a força da profetisa. Em Tecoa Porã, as pessoas falavam e tinham gestos contidos; não apreciavam excessos e rispidez em seus atos. Enfim, os mbyás seguiam as formas de agir que a profetisa provavelmente usava para lidar com o branco.

Enquanto os tupiniquins e os mbyás da aldeia vizinha de Tecoa Porã, denominada Tecoa Boapy Pindo, fundada a partir de uma cisão, conviviam com a presença intensa e constante de membros de instituições religiosas e do governo, os mbyás de Tecoa Porã tinham um padrão de interação com a sociedade nacional distinto. Não quero dizer com isso que em Tecoa Porã as pessoas se esquivavam de qualquer encontro com o branco. Pelo contrário, dependiam dele para sua subsistência, como veremos a seguir com relação ao turismo. Os mbyás negociavam as indenizações que a empresa florestal deveria oferecer por ter destruído e os expulsado de lugares 
sagrados e conviviam com turistas. Minha intenção aqui é enfatizar o fato de que os mbyás dessa localidade ainda sentiam a forte presença da profetisa, o que os levou a tecer uma cuidadosa e específica relação com a sociedade nacional. Em Tecoa Porã, havia uma tensão latente entre aqueles que iam para as festas nas cidades, bebiam e jogavam futebol, e aqueles que eram fiéis aos ensinamentos da profetisa e abominavam tais práticas. Eram os últimos que mantinham a organização da aldeia e conseguiam impedir que os homens trabalhassem na cidade. Um desses reclamou dessa "proibição", que não existia em outros grupos com os quais ele já morou. Enfim, os problemas e soluções cotidianos mostravam a reminiscência da profetisa que parecia ainda vivificar e fazer permanecer Tecoa Porã.

A singularidade dessa localidade se revela quando nos deparamos com a realidade de outros grupos mbyás. Darella (2001) mostrou que os mbyás localizados no litoral do estado de Santa Catarina estavam envolvidos em reuniões, discussões, encontros que visavam estabelecer reivindicações frente à sociedade nacional. Esses mbyás estavam preocupados em ter garantidas suas terras, educação e saúde. Em tais comunidades, os xamãs sonhavam e mostravam as novas terras que deveriam ser ocupadas e, conseqüentemente, demarcadas para garantir a utilização das mesmas (op. cit.:22). De acordo com esta autora, as estratégias dos grupos de Santa Catarina não passavam por migrações, invisibilidade e silêncio - caso dos mbyás de Tecoa Porá -, mas estavam baseadas em falas e escritos realizados por eles acerca de reivindicações frente à sociedade nacional (op. cit.). Enfim, essas atitudes revelam que maneiras diversas de reagir estão sendo elaboradas pelos mbyás, todas baseadas em seu ethos. A fala, assim como a mobilidade, é um dos princípios essenciais do xamanismo mbyá, o qual é estruturador de seu complexo sócio-cosmológico, o meio de acesso aos seres imortais.

Pode-se dizer que, no estado de Santa Catarina, os mbyá dinamizavam a fala, o fluir que mantinha o corpo ereto, para se relacionar com os seus outros. Nas assembléias, a língua parecia se exercitar até ganhar uma dimensão extraordinária, que alcançava os mbyás de outras localidades reunidos ali e os brancos. Os guarani-kayovás eram, até então, o exemplo máximo de como um subgrupo guarani usava o discurso nessas reuniões (Almeida 1996; Levcovitz 1998). A preocupação dos mbyás de Santa Catarina com a demarcação das terras indígenas, em certa medida, era uma novidade. Melià (1992) e Ladeira (1992) chamaram a atenção para o fato de que muitos grupos mbyás eram contrários à demarcação de suas terras ou à aquisição de títulos de propriedade, pois acreditavam que com isso estariam limitando e deformando o seu mundo.

Por sua vez, em Tecoa Porã, os mbyás guardavam a fala para as cerimônias, isto é, atualizavam-na no interior do socius, e faziam uso, especialmente, da mobilidade e do silêncio nas suas relações com os brancos. Eles optaram pelo caminhar, pelo movimento dos corpos na interação com os brancos. O cacique nas suas viagens e o uso do turismo como uma fonte de subsistência, como veremos adiante, esclareciam ou exemplificavam a escolha pelo movimento que esses guaranis fizeram.

Portanto, em Tecoa Porã, o ritmo da vida estava associado aos princípios do xamanismo instaurados pela profetisa, por exemplo, a mobilidade. Como já foi discutido, os homens mantinham a reprodução social ao caminhar por rotas ordinárias em direção a outras aldeias com a finalidade de estabelecer relações matrimoniais, sanar 
conflitos, transmitir informações etc. Por sua vez, as mulheres estáticas nas rodovias pareciam captar o movimento dos turistas para garantir a sobrevivência do grupo.

Segundo Cadogan (1960:136), a agricultura passou a ocupar uma importância secundária em muitos grupos mbyás, portanto, não é mais a principal atividade de subsistência. Em Tecoa Porã, a agricultura também não era mais central; na verdade, ela se resumia a algumas árvores frutíferas e à horta de um único homem. $\mathrm{O}$ turismo passou a ocupar o espaço da atividade agrícola nessa comunidade como uma nova fonte de subsistência. Denomino de turismo a atividade que membros da nossa sociedade realizam, quando buscam uma mudança de ambiente e paisagens mais agradáveis. $O$ turista é aquele que pretende sair de sua vida cotidiana, mas dentro de certos limites, pois ele não quer correr nenhum risco como o de perder sua identidade. Segundo Rossel (1988:2), o turismo é uma forma de viver uma experiência breve, mas intensa, em um mundo diferente. Para ter essa experiência interessante ou para se estranhar, o turista, ainda, segundo esse autor, quer empregar bem o seu dinheiro. Os mbyás de Tecoa Porã apresentavam-se como uma das dimensões dos serviços consumidos pelos turistas. Eles assumiam a posição de índios exóticos e vendiam, além dessa imagem, arcos, flechas, cestas, zarabatanas, chocalhos, leques, esculturas em forma de animais, colares, bolsas, enfim, bens materiais que complementavam a figura do exótico. Além disso, as crianças mbyás faziam apresentações de danças e cantos matrimoniais para os turistas verem, fotografarem e se julgarem diante da pureza primordial. $\mathrm{O}$ artesanato e as apresentações eram feitos exclusivamente para turistas; os mbyás não se utilizavam de nenhum dos artefatos que vendiam e as danças que eles realizavam não lembravam em nada as praticadas na casa de reza. Quando um turista vai ao encontro dos mbyás, ele pretende passar por uma experiência de estranhamento. Contudo, ele já tem definido que tipo de estranho quer encontrar. Por sua vez, os mbyás, sabendo desta expectativa dos brancos, transfiguravam-se no índio esperado e desejado. Nesta atuação, os mbyás recepcionavam as excursões escolares que chegavam à aldeia ávidas pelo exótico e coordenavam as danças.

Os mbyás não tinham nenhuma denominação especial para os turistas; todos os brancos eram chamados de juruá. Para fins analíticos, divido os turistas com os quais eles se relacionavam em dois tipos: o primeiro compreendia grupos pequenos que trafegavam pela rodovia; o segundo tipo era formado por alunos de escolas em excursões acompanhados de seus professores. O primeiro tipo de turista aparecia nos fins de semana e feriados. De dezembro a março, esse turista surgia com mais freqüência e promovia uma fartura na aldeia. Os mbyás aguardavam-no na rodovia que dista aproximadamente um quilômetro da aldeia. Na beira dessa estrada, os mbyás expunham os objetos e esperavam que o turista em trânsito parasse e comprasse o artesanato. A forma como se dava esta interação diferia muito da maneira como os regionais abordavam os turistas. Os regionais iam até às praias, aproximavam-se das pessoas e vendiam seus serviços. Por sua vez, os mbyás ficavam na rodovia litorânea, ou seja, próximos às praias repletas de pessoas, como se quisessem captar o movimento dos turistas. Os mbyás não se deslocavam para vender seus objetos: preferiam estar no caminho por onde os turistas se deslocavam.

Já o segundo tipo de turista aparecia quase toda semana ao longo do ano letivo. Tratava-se de grupos de crianças ou adolescentes acompanhados de seus professores, provenientes das escolas dos diversos municípios próximos à Tecoa Porã. Esse turista, diferentemente do outro que permanece na rodovia, ia à aldeia, levava 
alimentos e roupas e comprava pouco artesanato. Os alimentos eram distribuídos, por algum homem adulto, entre as residências ou núcleos domésticos de acordo com o número de pessoas que viviam nele.

Em Tecoa Porã, havia um pátio, onde eles recepcionavam os turistas e expunham os objetos a serem vendidos. Algumas vezes, o primeiro tipo de turista ia até a aldeia, dava uma volta pela aldeia e nem sequer descia do carro. Alguns da janela do carro faziam perguntas como: "Vocês têm religião?" ou "Como vocês se casam?". Aqueles que desciam de seus carros, imediatamente encontravam uma grande mesa, onde estava exposto o artesanato. Os mbyás esperavam silenciosos que as compras fossem feitas.

$\mathrm{O}$ artesanato era feito pelos casais com seus filhos. Um núcleo doméstico coletava na mata a matéria-prima para a confecção dos objetos a serem vendidos. Os homens só faziam os objetos de madeira, como esculturas em forma de bichos, arcos e flechas; as mulheres faziam a grande maioria do artesanato, os trançados com fibra de palmeira, por exemplo, bolsas, leques, cestos de vários tamanhos e formatos, chocalhos etc. Eram as mulheres que dominavam as vendas. Os homens sem esposas ou filhas na aldeia dependiam, geralmente, de velhas viúvas para ter dinheiro com o turismo, pois eles davam a matéria-prima a essas senhoras, que confeccionavam o artesanato, vendiam-no e davam a metade do dinheiro para eles. Portanto, o dinheiro arrecadado na venda ficava com o grupo que fizera e vendera os objetos. Essa forma de comércio já foi causa de problemas em Tecoa Porã, quando uma excursão chegou à aldeia e as pessoas compraram todos os leques de uma única jovem. Os outros mbyás ficaram irritados com essa atitude dos brancos, acharam que o cacique deveria ter interferido, pois todos deveriam ter seus objetos comprados.

Em Tecoa Porã, as pessoas eram extremamente reservadas, algumas iam às suas casas quando chegava algum branco na aldeia e permaneciam por lá até ele partir. Os mbyás escolhidos para lidar com essa tarefa, a venda, geralmente eram as filhas, irmãs ou mães. Quando algum turista chegava à aldeia, essas mulheres ficavam em silêncio, respondiam às perguntas que lhes eram feitas quando queriam e aguardavam as trocas comerciais. Na rodovia, também, elas esperavam o turista parar e perguntar pelo preço de algum objeto. Quem tomava a iniciativa em tais situações de compra-venda era o turista.

A meu ver, o que acontecia nesta interação com o branco parecia ser que os mbyás de Tecoa Porã ficavam à espera dos turistas, posicionavam-se no fluxo desencadeado pelos mesmos nas rodovias. Os mbyás encontravam-se no movimento dessas pessoas que estavam vivendo em um tempo e espaço não-cotidiano de suas vidas. Assim, os mbyás dessa localidade se punham nas rotas dos turistas. O movimento dos turistas era culturalmente gramatical com relação aos mbyás, pois se tratava da mesma regra de conduta, mas com significados obviamente diversos. Uma possível explicação para o fato de que os mbyás, com sua reserva extrema, escolheram lidar com esse segmento da nossa sociedade, o turista, que se imaginava em um conjunto de serviços, do qual o exótico índio fazia parte e deveria servi-lo e recepcioná-lo de forma agradável e não com timidez ou receio estava nesta gramaticalidade cultural.

Em Tecoa Porã, os mbyás optaram ou encontraram no turismo uma fonte de subsistência e uma forma de relação com o branco que seguiam os moldes de seu complexo sócio-cosmológico. Nesse sentido, a mobilidade, a vivência em uma superposição de territórios e a efemeridade pontuavam essa interação. Nessas relações mantidas 
com os turistas, acontecia uma inversão da conduta entre esses e os mbyás, pois, quando os turistas se aproximavam, os mbyás estavam estáticos, passavam a ser "espectadores" do movimento deles numa situação em que pareciam captar e compartilhar de seu trânsito.

Além da mobilidade, existia uma outra regra de conduta que aproximava os mbyás dos turistas: era a ocupação espacial através da superposição de dimensões em uma região. E tal regra tinha significado distinto para cada caso. No caso dos mbyás de Tecoa Porã, quando um xamã guiava um grupo, eles caminhavam por áreas onde outros grupos ou os brancos atuavam. Contudo, eles pareciam seguros de não estar cometendo nenhuma violência ou invasão de territórios, pois tudo se passava como se, no fervor das profecias do xamã ou no simples movimento por trilhas ordinárias, eles estivessem vivendo em uma dimensão e os brancos, outros índios e os mbyás de outras aldeias em outras dimensões. Para os mbyás, tudo se passava como se um grupo conformasse seu território ou sua região de atuação de tal forma que não impossibilitasse outros de existirem e aconteceram ao mesmo tempo e no mesmo espaço. Nesse sentido, seria possível que grupos, com intenções distintas, ocupassem um mesmo espaço. Obviamente, um grupo mbyá não podia ignorar as adversidades que surgiam durante as caminhadas, mas estas não tornavam uma área de atuação estanque e limitada por outras. Por sua vez, os turistas conformavam um segmento da sociedade nacional que vivia ou se imaginava em uma outra dimensão, diferente de sua vida ordinária. Estavam em uma situação de suspensão, superposta à vida cotidiana das pessoas que viviam por onde eles passavam, semelhante à regra de ocupação espacial mbyá, baseada na superposição de territórios. Nesse sentido, o turismo é uma das faces da nossa sociedade que mais se coaduna com o modo de ser mbyá, pois o turista vive esse momento de interrupção, em uma outra dimensão, e está desligado, nesse instante, de uma vida estática. A condição dos turistas de estar de passagem, de transitar por espaços, de alcançar outra dimensão, parecia estar associada a valores centrais da cosmologia mbyá. O turista era aquele que menos interferia na vida dos mbyás, pois ele estava de passagem e vivia uma dimensão espaço-tempo singular. As interações que ele mantinha com os mbyás eram efêmeras, momentâneas, passageiras e fugidias. Exatamente quando o turista viajava pelas estradas, i.e., estava literalmente em movimento e em uma dimensão extra-cotidiana de sua vida, os mbyás o aguardavam. Nas rodovias, os mbyás pareciam captar ou compartilhar do movimento do turista. Desconheço qualquer atitude dos mbyás de Tecoa Porã de ir atrás dos mesmos nas praias, cidades ou ir vender seus artesanatos em lojinhas nos centros urbanos.

Resumidamente, pode-se dizer que em Tecoa Porã tudo se passava como se as pessoas vivessem em uma determinada dimensão, que englobava outras aldeias mbyás, com as quais eles interagiam, diferente das dimensões onde viviam os brancos, outros grupos indígenas e mbyás distantes. Nessa dimensão, os mbyás de Tecoa Porã sabiam conviver e controlar a proximidade da sociedade nacional. Assim, eles faziam com que as interferências do branco não fossem um risco à referência espacial que utilizavam para se realizar e expandir. Só assim os mbyás de Tecoa Porã conseguiam conviver próximos de grandes cidades e de balneários turísticos. Eles desenvolviam uma situação de contato interessante, que os resguardava, de certa forma, da intromissão nefasta da sociedade envolvente. Esses mbyás conseguiam se proteger, ao construir essa dimensão singular de quase invisibilidade ou presença silenciosa onde a vida mbyá acontecia e eles escolhiam com quem interagir intensamente. 
Os mbyás conviviam com a sociedade nacional e procuravam ter poucos momentos de interação conflituosos. No entanto, eles escolheram ter relações com os turistas. O turismo ocupava grande parte do cotidiano da aldeia. Entretanto, alguns problemas graves surgiam nessa interação. Em Tecoa Porã, os mbyás abandonaram a agricultura, caça e coleta e estabeleceram o turismo como a principal fonte de subsistência. Desse modo, a alimentação do grupo passou a ser, basicamente, de produtos comprados na cidade, como arroz, feijão, macarrão, farinha. A carne passou a ser escassa. Com esse tipo de alimentação, eles ficaram mais suscetíveis à desnutrição e às doenças. Os mbyás também perderam uma grande fonte nutritiva, o milho. Esse alimento era usado abundantemente nos períodos de jejum, quando se evitava a carne. Os mbyás utilizavam um tipo de milho específico, que eles traduziam como "milho de índio". Há pouco tempo, duas anciãs da aldeia conseguiram sementes desse milho com outros mbyás; contudo, como ninguém plantou, com o tempo, as sementes estragaram. Nas caminhadas rituais em busca da terra sem mal, os profetas sempre traziam consigo sementes do "milho de índio".

Em Tecoa Porã, o turismo foi incorporado no nicho temporal que, uma vez, o ciclo agrícola compunha ${ }^{14}$. Por mais que os mbyás não pratiquem mais a agricultura, o tempo do cultivo dos alimentos ainda persiste. $\mathrm{O}$ milho, por exemplo, era plantado nos meses de setembro, outubro e era colhido em janeiro e fevereiro, quando compunha o prato principal do banquete do ritual de nominação. Nessa cerimônia, as pessoas de outras aldeias vinham participar das festas ou traziam seus filhos para receber um nome da profetisa. Parece que o "ciclo do turismo" se sobrepôs ao ciclo agrícola e passou a coordenar o tempo. O fato de o turismo ser mais intenso nos meses de janeiro e fevereiro e, portanto, promover um excedente de produtos na aldeia, no mesmo período em que o milho era coletado e produzia uma fartura na aldeia, é algo curioso. Nesses meses, aconteciam os rituais de nominação. Os mbyás se preparavam para esta época de turismo intenso já no mês de outubro, quando a matéria-prima para a fabricação do artesanato era coletada e a feitura dos objetos era iniciada. Esse período de preparação para o turismo coincidia com o momento quando se iniciava o plantio do milho. Ao que parece, o turismo foi incorporado ao calendário das festas mbyás de Tecoa Porã e passou a coordenar o ritmo de vida da aldeia no lugar do ciclo agrícola do milho.

Diante do exposto, percebe-se que uma das principais técnicas utilizadas no xamanismo, que permitia a transcendência da condição humana, organizava a ocupação espacial e promovia o ritmo de vida da aldeia, i.e., a mobilidade, parecia dinamizar todos os momentos da vida ordinária dos mbyás, assim como momentos cerimoniais de busca da terra sem mal. A existência da região ou do espaço de atuação dos mbyás parecia depender do constante fluxo de pessoas pelas rotas ordinárias. Por sua vez, a utilização do turismo como principal fonte de subsistência parecia depender, para que acontecesse, do fluxo dos brancos pelas rodovias, ou melhor, os mbyás deviam captar e compartilhar do trânsito dos turistas. Nesse sentido, uma visão extrema poderia dizer que, em Tecoa Porã, o movimento estava em tudo, até nos brancos, os sedentarizadores por excelência.

Sílvia Guimarães é doutora em Antropologia Social

pela Universidade de Brasília e antropóloga do Iphan (Instituto do Patrimônio Histórico e Artístico Nacional). 


\section{NOTAS}

1 Agradeço aos pareceristas da revista Campos pela leitura cuidadosa que fizeram do artigo e por suas contribuições. Este trabalho é resultado da pesquisa que realizei com os guarani-mbyás de Tecoa Porã, no estado do Espírito Santo, em 1997.

2 Ver artigo de Darella (2004) e sua discussão sobre o tema da territorialidade e territorialização guarani e a relação que estabelece com outros trabalhos.

3 Os autores que utilizo aqui não procuraram identificar quais subgrupos guaranis descendem dos guaranis do século XVI de que eles tratam nos seus escritos. Contudo, não acredito que isto prejudique a tentativa de análise proposta aqui, já que não estou estabelecendo nenhuma genealogia entre os mbyás de Tecoa Porã e os guaranis do século XVI, mas uso esses dados a título de comparação com os mbyás de hoje e para problematizar o caso em discussão.

4 Ver artigo de Carneiro da Cunha e Viveiros de Castro (1986) sobre a relação entre guerra e a produção futura de nomes e pessoas.

5 Nos relatos deste período, dificilmente, as mulheres surgiam fundando uma aldeia. Essa ausência do papel das mulheres xamãs nestes relatos pode ser resultado da leitura que cronistas, especialmente jesuítas, faziam da condição feminina.

6 Uso o grafia de Soares (1997), contudo, no caso dos guarani-mbyá em discussão, uso uma grafia mais simplificada, próxima do português.

7 Os mbyás colocam os xamãs numa gradação, que vai dos xamãs mais poderosos aos menos. Assim, existe xamãs que são só curadores, existem outros que são cantores e dançarinos "fortes" e existem outros que acumulam todas essas funções, são os profetas, que guiam um grupo em busca da terra sem mal e são lideranças políticas e religiosas. Quando falo de xamã neste artigo, estou me referindo ao tipo do profeta.

8 Não estou querendo dizer aqui que os mbyás de Tecoa Porã apresentam uma novidade na etnologia indígena com relação os deslocamento das pessoas, mas discutir uma possível explicação para essa realidade, para o específico deslocamento que realizam.

9 Ver Cadogan (1949, 1950, 1997) e Ladeira (1992) sobre a procedência das almas-palavras dos guarani-mbyás.

10 A autora se refere a todos os guaranis da atualidade, sem especificar de que subgrupo está tratando.

11 Não vou tratar neste trabalho do sistema de parentesco mbyá por não ter dados suficientes para apresentar uma discussão. Contudo, menciono alguns casos sobre a residência para mostrar a força do prestígio da profetisa que atraía pessoas para a sua aldeia. A convivência com esta xamã significava a possibilidade de alcançar a terra sem mal. Isto era determinante na escolha do local de residência para uma pessoa. Um estudo de parentesco sobre a região de atuação de uma aldeia esclareceria muito sobre os mecanismos que acionavam o trânsito de pessoas, mas deixo esta análise para um outro momento. Com relação a este tema do parentesco, discordo de Shapiro (1987:131) e Clastres (1978:41) quando afirmam que os profetas tupi-guarani estavam numa posição separada da esfera dos laços de parentesco e das alianças políticas, pois, assim, eles poderiam se mover livremente entre muitas aldeias, mesmo entre aquelas que estavam em guerra. Talvez aqueles profetas que viviam em trânsito constante entre as aldeias estivessem fora dessas alianças, mas os profetas que fundavam uma unidade social precisavam e faziam alianças de parentesco e políticas com outras aldeias, pois isto era vital para a reprodução do grupo.

12 Segundo o padre Montoya, no século XVI, pareha era o mensageiro dos guarani (Soares 1997:149).

13 A empresa Aracruz Ceulose se localiza no município de Aracruz, no estado do Espírito Santo. Ela é uma das maiores produtoras do mundo da polpa-celulósica branqueada de eucalipto, utilizada na fabricação de papéis brancos. Em 1996, esta companhia supriu $22 \%$ da demanda mundial deste produto e exportou $93 \%$ da sua produção, principalmente para a Europa (33\%), América do Norte (37\%) e Ásia (23\%). Ela domina todos os meios de produção de que necessita, desde as plantações de eucalipto até um porto privado para a exportação (Portocel). A sede da mesma está no Rio de Janeiro, a sua fábrica e o porto estão no estado do Espírito Santo e as plantações de eucalipto estão nos estados do Espírito Santo e Bahia. A história dessa empresa no Brasil está relacionada com o massacre de comunidades tupiniquim no Espírito Santo e regionais na Bahia. Na década de 
1990, tal companhia viu ameaçado o seu mercado consumidor devido à atuação das lideranças tupiniquins e mbyás e do CIMI, que pretendiam retirar o "selo verde" da mesma. Com esse selo, uma companhia atesta que sua matéria-prima florestal e os processos produtivos utilizados estão de acordo com procedimentos econômicos, sociais e ambientais internacionalmente estabelecidos, nos quais danos às sociedades tradicionais são abominados. O cacique tupiniquim viajou até a Noruega, país de origem de um dos maiores acionistas, para denunciar os massacres e invasões sobre territórios indígenas feitos pela Aracruz Celulose.

14 Estou me referindo ao caso dos guarani-mbyá de Tecoa Porã e não à realidade de outras sociedades que ainda apresentam fortemente arraigado o ciclo agrícola. 


\section{REFERÊNCIAS BIBLIOGRÁFICAS}

ALMEIDA, R. 1996. “O Caso Guarani: o que dizem os vivos sobre os que se matam”. In Povos Indígenas no Brasil: 19911995. São Paulo: linstituto Socioambiental.

BARTOLOMÉ, Miguel A. 1989. “Nacion y Etnias en Paraguay”. América Indígena XLIX(3): 407-17.

CADOGAN, Leon. 1960. “En Torno a la Aculturación de los Mbyá-Guarani del Guairá". América Indígena XX (2): 13350.

CHASE-SARDI, Miguel. 1989. "Situacion de los Indígenas en el Paraguay". América Indígena XLIX(3): 419-29.

CICCARONE, Celeste (org.). 1996. Revelações sobre a Terra: a memória viva dos guarani. Vitória: UFES. PUC.

. 2001. Drama e Sensibilidade. Migração, xamanismo e mulheres Mbyá Guarani. Tese de Doutorado. São Paulo:

CLASTRES, Hélène. 1978. Terra sem Mal. São Paulo: Brasiliense.

DARELLA, Maria Dorothea P. 2001. "Reflexões sobre a Palavra (falada e escrita) em Guarani e Português em Busca de yvy porã/tekoa porã no Litoral do Estado de Santa Catarina". Encontros Teológicos 16(31): 51-94. Florianópolis.

GUIMARÃES, Sílvia. 2001. Os Guarani-Mbyá e a Superação da Condição Humana. Dissertação de mestrado. Brasília: Universidade de Brasília.

. 2004. "A Marcha Cerimonial Guarani-Mbyá". Anuário Antropológico 2002-2003: 151-92.

KRAMER, Ana M. G. 1988. "Mujer y Sociedad Guarani: una propuesta comparativa”. Estudos Ibero-Americanos XVI(2): 177-194.

LADEIRA, Maria Inês M. 1992. “O Caminhar sob a Luz": o território Mbyá à beira do oceano. Dissertação de mestrado. São Paulo: PUC.

LEVCOVITZ, Sérgio. 1998. Kandire: o paraíso terreal - o suicídio entre índios guaranis do Brasil. Rio de Janeiro: Espaço e Tempo.

LITAIFF, Aldo. 1999. Les Fils du Soleil: mythes et pratiques des indiens mbyá.guarani du littoral du Brésil. Thèse de Ph.D. Montreal: Université de Montréal.

MELIÀ, Bartomeu. 1990. "A Terra sem Mal dos Guarani. Economia e profecia". Revista de Antropologia 33: 33-46. 1992. La Lengua Guaraní. Historia, sociedad y literatura. Madrid: Mapfre.

ROSSEL, Pierre (org.). 1988. Turismo: la producción de lo exotico. Copenhaguen: IWGIA.

SHAPIRO, Judith. 1987. "From Tupã to the Land without Evil: the cristianization of the tupi-guarani cosmology". American Ethnologist 14(1): 127-39.

SOARES, André L. R. 1997. Guarani: organização social e arqueologia. Porto Alegre: EDIPUCRS. 


\section{As Marchas Prosaicas de um Grupo Guarani-Mbyá}

\section{RESUMO}

Este artigo pretende discutir a mobilidade, elemento constituidor do xamanismo guarani-mbyá, na realização das marchas ordinárias de um grupo e sua gramaticalidade cultural com o movimento dos turistas da nossa sociedade, fonte de subsistência do grupo guarani-mbyá em discussão.

PALAVRAS-CHAVE: Guarani-Mbyá, xamanismo, mobilidade, turismo.

\section{The Prosaic Marches of a Guarani-Mbya Group}

\section{ABSTRACT}

This article discusses the mobility of a Guarani-Mbya Indian group in its relations to tourism. Mobility is an essential part of Guarani-Mbya shamanism implying ordinary marches. As part of the groups' cultural grammar, such mzobility is connected to the mobility implied in tourism, which is, presently, an important source for the economic subsistence of the group. KEY WORDS: Guarani-Mbya, shamanism, mobility, tourism. 